\title{
The Bible in discussion: Three recent South African publications on Scripture
}

\author{
F E Deist \\ University of South Africa
}

\begin{abstract}
Three recent South African books on Scripture from various theological traditions and social circles (one Reformed, one Dutch Reformed and one Methodist, two by white authors and one by a black author) are discussed in order to evaluate their arguments and ascertain their points of difference, with a view to enhancing a meaningful South African dialogue on Scripture.
\end{abstract}

On my desk lie three recent publications dealing with the Bible and biblical hermeneutics (Mosala 1989; Potgieter 1989; Van Wyk 1990), each grappling with the discussion in the relevant author's theological tradition in South Africa. Mosala discusses the situation in black theology, Potgieter provides us with a Dutch Reformed view, and Van Wyk writes on the discussion within the Reformed Churches (Gereformeerde Kerke).

While South African politicians are presently trying to assist the birth of a new South Africa' through negotiations it would perhaps not be inappropriate to let these three publications take their places around a negotiating table to hammer out some sort of a consensus in respect of a 'South African' view of Scripture - or to identify the stumbling blocks in the way of such a 'united' view of Scripture.

I shall first discuss the three publications and then try to determine their differences, in order to formulate the areas of disagreement. For the sake of convenience I shall present my own translation of quotations from the Afrikaans texts.

\section{VAN WYK (1990)}

Van Wyk presents us with a clearly written book in which the views of other (Reformed) scholars are presented in all fairness, and in which some older views of members of the Gereformeerde Kerke (GK), such as those of the well-known J D du Toit (Totius), are overtly criticised. Van Wyk's rejection of reformed orthodoxy's 
view of Scripture already indicates a sharp departure from earlier GK views. An example can illustrate the point. In the well-known Du Plessis trial of the Dutch Reformed Church, J D du Toit hailed reformed orthodoxy as the golden age of reformed theology (Die Kerksaak 1932:128):

With regard to the term 'scholasticism' I would say this: if used in a positive sense I can go along with it, since the men concerned were people writing in the blooming period of our theology and our Reformed Church...Unfortunately the term 'scholasticism' is often used in a negative sense...The men who worked after Calvin, were the $\mathrm{Re}$ formed scholastics, in so far as they worked out further and broader the principles laid down by Calvin. They were, therefore, not scholastics in the negative sense of the word. I can mention Amesius...I can also mention Voetius, and others.

Van Wyk (1990:10) says about this period:

Revelation was intellectualistically identified with a series of truths... The criterion governing orthodox views of Scripture was...a comprehensive doctrinal system; an epistemological formalisation of Scriptural authority was constructed, and the connection between salvational authority and the scopos of Scripture became obsolete... Typical of the time is...Voetius, who subscribing to a rigid mechanical view of inspiration, polemised against Calvin's doctrine of Scripture.

What Du Toit regarded as the 'golden age' of Reformed theology Van Wyk thus views as a period of stagnation. Likewise, Du Toit (Die Kerksaak 1932:128) lashes out against 'higher criticism' - because it 'is unscientific' - and dodges the question of whether one can regard the Bible as the Word of God and, at the same time, accept that it contains mistakes of chronology (Die Kerksaak 1932:136-137); Van Wyk (1990:61-62 - cf 44-46), however, affirms: 'A [historical] critical approach thus does not imply theological liberalism undermining the authority of Scripture.'

This difference of opinion and the amount of disagreement among present-day GK theologians on the question of the real nature of scriptural authority do not, according to Van Wyk (1990:31-32, 60-61), amount to 'alarming tension' among GK theologians in South Africa.

\subsection{The key concept}

Van Wyk first traces the Reformed view of Scripture from Augustine, through Calvin, Bavinck, and Berkouwer to present-day theologians of the GK. The key concept in this overview is revelation, divine revelation (Van Wyk 1990:46): 
- 'It is very important,' writes Van Wyk (1990:2), 'to note that Augustine approaches Scripture as divine revelation.'

- In my view the...most important thing that has to be said about Calvin's view of Scripture is that we are confronted in Scripture by God's revelation to humankind and not with human experience' (Van Wyk 1990:5);

- 'Bavinck's doctrine on Scripture closely links up with his doctrine on revelation. In fact, for him religion rests upon revelation...' (Van Wyk 1990:11);

- '[Berkouwer] puts such emphasis on the human nature of Scripture...that one may rightfully ask whether the revelational character of Scripture remained untouched' (Van Wyk 1990:16);

- 'In my opinion the report [God met ons], because of its philosophical premise, overemphasized the human side of Scripture' (Van Wyk 1990:25).

- When Van Wyk (1990:40-50) presents us with his own doctrine on Scripture he subdivides the theme into revelation, divine revelation, salvational revelation ('heilsopenbaring'), authoritative revelation, and trustworthy revelation.

\section{The argument}

How do we know that the Bible consists of divine revelation? Van Wyk is sceptical about mere rational argumentation in this regard. That the Bible consists of divine revelation cannot be proved by rational argument, but can only be deduced from the Bible's own witness (Van Wyk 1990:47-48) and professed by believers. For that reason any theory of inspiration or inerrancy trying to formally secure the divine nature of the Bible's contents is to be rejected. Consequently, reformed scholasticism and fundamentalism have to be rejected (Van Wyk 1990:43).

By the same token any attempt at interpreting the Bible without the premise of faith in the Bible as divine revelation, that is, any attempt at rendering the Bible a mere human book or document containing human experience of (or reaction to) divine revelation, is to be rejected (Van Wyk 1990:60).

The Bible can only be understood and used properly by a person committed to the faith to which the Bible invites him. Concepts such as sola Scriptura, canon, the inspiration, authority, clarity and trustworthiness of Scripture cannot be discussed in the abstract, that is, apart from the function of Scripture in the community of believers, since these concepts stand in the closest relation to the message of salvation proclaimed by the biblical texts.

The Bible should, however, not be viewed as 'inerrant' - at least not when 'inerrancy' refers to modern-day historical consistency and accuracy (Van Wyk 1990:30). To add 'inerrancy' to the 'trustworthiness' of the Bible would require a mechanical 
view of biblical inspiration. The Bible indeed contains 'mistakes', or rather a certain amount of 'irregularity' (oneffenhede) (Van Wyk 1990:45-46).

Because Scripture can only be called the infallible Word of God in the context of the Bible's function (that is, in the context of the explication of the Bible under the enlightment by the Holy Spirit), and not in abstracto, it would be fundamentalistic to speak of 'biblical proof' (Skrifbewys) for this or that view - as was done in the case of a few synodal decisions of the past (Van Wyk 1990:56-58), where the Bible only had to supply the 'proof for a view already agreed upon before listening to the Bible. An exegetical biblical view or pronouncement invoked in support of theological and ecclesiastical arguments should rather be looked upon as an 'appeal to Scripture' (Skrifberoep) (Van Wyk 1990:55), since the exposition of Scripture - although done under the inspiration of the Holy Spirit - remains human work.

In appealing to Scripture theologians should

- never try to invoke Scriptural support for any matter that lies outside the (saivation-historical) scopus of biblical authority;

* be critically aware of the presuppositions flowing from their faith and culture (Van Wyk 1990:37, 56);

- be conscious of their epistemological point of departure that could 'colour' their conclusions (Van Wyk 1990:31, 37) ;

* adhere to certain rules for sound exegesis (Van Wyk 1990:51-54); and

- be alert to the danger of 'conclusivism' (i e viewing anything that can be logically deduced from Scripture as scriptural revelation - Van Wyk 1990:53).

\section{Discussion}

In terms of the classical or orthodox Reformed view of Scripture, Van Wyk's articulate exposition indeed makes pleasant reading. His insistance

* that the Bible is a religious document,

- that the faith of Bible readers plays a major role in their interpretation of biblical texts - indeed, that faith provides the basis for all biblical interpretation,

- that theology should not be done in abstracto, but from within the context of the believing community,

- that obedience to the message of Scripture is of greater importance than 'orthodox' theological theories,

should be welcomed and taken seriously, as should also his functional definitions of authority, infallibility, clarity and such Reformed thought categories. Likewise, his sensitivity for our African context (Van Wyk 1990:38) and the implied warning that we should not be practising theology from a 'white' perspective only, should be applauded. 
The questions Van Wyk puts to Van Huyssteen (1986) regarding the relationship between philosophy and theology perhaps point to the Achilles heel of his argument - as will become clear in our discussion of Mosala's biblical hermeneutics.

After having admitted that theology should have intellectual integrity, Van Wyk (1990:37) asks:

It may be true that every theologian wittingly or unwittingly employs a philosophical epistemology, but does this imply that theology should be made dependent upon philosophy? Should it necessarily be a philosophical model of rationality? And should theological insights be continuously adapted as models of rationality shift?

Unfortunately, he does not give any indication of what a non-philosophical or theological (?) model of rationality would comprise. Neither does he indicate how, after having admitted that theology should have intellectual integrity, he would escape from the problem of a philosophical epistemology and methodology.

Van Wyk (1990:39) is also sceptical about the category of 'human experience' as a constitutive aspect of 'divine revelation', a category that would - if acknowledged - seriously call for epistemological reflection when speaking about revelation and the Bible.

One gets the impression that Van Wyk (subconsciously) realises that acknowledging, all too overtly, a human element in divine revelation would

- involve epistemological questions on the level of revelation, which would

* question the objectiveness of 'revelation', and consequently

* biblical authority.

Is it not perhaps precisely the notion of authority - or rather a particular cultural definition of authority - that necessitates this safeguarding of the objectiveness of revelation? And, if so, has Van Wyk really put all the (cultural presuppositional) cards on the table?

Has Van Wyk then really escaped from an attempt to 'safeguard Scripture by means of a humanly-rational theory about Scripture?' (Van Wyk 1990:44).

Van Wyk does not touch upon the question of the nature of theological pronouncements either. Are they to be taken realistically, nominalistically, metaphorically, or what? Such reflection is important, for what is the sense of an objective revelation if our knowledge of that revelation and our pronouncements about that revelation are human? What then is the status of theological knowledge? And in view of these questions, is it really possible to escape a debate on philosophical epistemology? 
Furthermore, if our knowledge of revelation - in spite of the enlightment from the Holy Spirit - can remain 'subjective', how was it possible for the biblical authors to remain untouched by this typically human 'subjectiveness'? If their witness indeed remained untouched by their subjectivity, were they then not of necessity mechanically employed? If 'inspiration' and 'enlightment' both are the work of the same Holy Spirit, why should they differ qualitatively? Are we not, in order to answer these questions, forced to pay attention to the nature of human knowledge, and therefore to philosophical epistemology?

\section{POTGIETER (1989)}

Potgieter's book covers virtually the same ground as Van Wyk's. However, Potgieter writes from the perspective of the tradition of the Dutch Reformed Church (DRC). His book also contains, as an addendum, a document accepted in 1986 by the General Synod of the DRC as a guide for its members on Scriptural authority and the use of Scripture.

Although Potgieter (1989:5) explicitly states that the synodal document was accepted as a guide for members of the DRC, he does not elaborate on the point. In terms of the history of the DRC it may, however, be important to note that such a document can never acquire official status, in the sense that while it voices the DRC's official dogma on Scripture, people (especially ministers of the DRC) deviating from such views do not become 'heretics'.

Dutch Reformed ministers are, in respect of dogma, only bound by the confessions of the church, not by synodal explanations of those confessions. This principle clearly emerged from the Du Plessis trial mentioned earlier. On that occasion the court accepted the argument presented by Du Plessis' advocate, De Wet (Die Kerksaak 1932:161-171, 225), that synodal explanations of the church's confessions do not form part of a minister's contractual oath and can therefore not be of a binding nature.

\subsection{The key concept}

Whereas Van Wyk's view of Scripture centres around the concept of revelation, Potgieter's centres around authority:

- 'A church functioning on the basis of a dubious authority should...expect to become irrelevant...' (Potgieter 1989:5).

* 'After the fall God's omnipotence and love had been revealed in the form of a coercive authority...' (Potgieter 1989:7).

- 'The maintenance of authority is indispensible for the existence and continuation of good order' (Potgieter 1989:7). 
- 'Without authority and faith....religion and theology cannot exist' (Potgieter 1989: $8)$.

- $\quad$...the spiritual trade mark of liberalism - on which presentday modernist theology foots - is...the rejection of authority' (Potgieter 1989:11).

- The authority with which ministers preach is the authority of the acting and speaking God himself (Potgieter 1989:12).

- 'Ministers of the Word ordained in an ecclesiatical office have the special task of proclaiming the Word of God with authority' (Potgieter 1989:13).

- That we are living in a world in which authority is being questioned on all fronts - including the ecclesiastical-religious arena - cannot be denied' (Potgieter 1989:14).

- 'There is but one ground for the authority of Holy Scripture, namely its divine origin' (Potgieter 1989:17).

- If a preacher should proclaim the Word of the Lord with authority the contents of his sermon cannot say anything else than what the Word of the Lord says' (Potgieter 1989:38).

- 'The result of believers' reflection on Scriptural revelation under the guidance of the Holy Spirit has over time been formulated as dogmas by the church...and are also endowed with authority' (Potgieter 1989:57).

I raised the question above (1.3) whether Van Wyk's emphasis on 'objective' revelation was not a covert plea for the restoration of a particular form of authority. In the case of Potgieter there is no doubt whatsoever. To him aushority lies at the root of any (sound) view of Scripture.

\section{The argument}

Authority implies a relationship between a superior and an inferior partner (Potgieter 1989:7-8). This also applies to divine authority, which forms the context within which we speak about scriptural authority. Contrary to Roman Catholic tradition, where authority is seated in the church, and Pentecostalism, where authority is seated in the Holy Spirit's guidance of the individual, and modernism's rejection of all forms of authority, 'Reformed Protestantism views Scripture as the infallible Word of God endowed with conclusive authority, the source of all true knowledge and the unquestionable norm for doctrine and conduct' (Potgieter 1989:8-12). Therefore preachers have a responsibility to preach the Word with authority.

The authoritative Word of God has different shapes ('gestaltes'): the revealed Word (Jesus Christ), the written Word (the Bible) and the proclaimed Word (the preaching by the church) (Potgieter 1989:15). Through the inspiration of the Holy 
Spirit, who ensured that the biblical authors understood and represented God's revealed Word correctly, the Bible presents us with the 'fixed form' of God's infallible Word, and it is this fixed form that has preserved the Word of God in all purity (Potgieter 1989:15-24). The biblical authors did not 'experience' the word of God - in which case their writings would contain a subjective element - but received it (Potgieter 1989:34). The fact that ordinary human beings wrote the Bible, therefore, did not lead to a Bible bound to those times and cultures ("tydgebonde/kultuurgebonde'). At most one could say that the product of inspiration was time and culture oriented ('tydbetrokke/kultuurbetrokke') (Potgieter 1989:26). The truth contained in the Bible is thus not a (subjective and relative) 'relational truth' but the objective truth (Potgieter 1989:35).

While the Holy Spirit inspired the biblical authors to write down the pure Word of God (Potgieter 1989:26) he gives the reader the understanding to read the pure Word of God from the Bible (Potgieter 1989:28). Yet, because of the total depravity of humankind, not all interpretations of the Bible lead to the discovery of the Word of God. It is only when the Bible is interpreted correctly that it can lead to the establishment of the authoritative truth (Potgieter 1989:28). Therefore we have to devise rules - deduced from Scripture itself (Potgieter 1989:32, 33) - for the correct interpretation of Scripture (Potgieter 1989:29). Even though there is no infallible method of interpretation (Potgieter 1989:51), such rules should at least take into account that the Holy Spirit inspired the biblical authors with a particular goal, which was not to present us with a 'historically correct, literal representation of the words of Jesus, but to bring home to us a particular divine truth' or 'message' (Potgieter 1989:30,44). Such rules should also pay attention to the literary, linguistic and theological context of biblical pronouncements. Because such skills are required the Word can never be severed from the 'interpreting church' (Potgieter 1989:53) and interpretation always requires a 'sound dogmatic basis' (Potgieter 1989:57).

When the Bible has been interpreted correctly the preaching flowing from such interpretation can also be called 'the Word of God' (Potgieter 1989:36-38). Yet, faith in the Word of God can only be created through the work of the Holy Spirit (Potgieter 1989:40).

It is only as long as the Bible remains the cornerstone of preaching that we can hope to proclaim the Word of God. When present-day societal problems provide the starting point for the preparation of a sermon - as in the case of contextual theology' - we cannot speak of true proclamation any longer (Potgieter 1989:45-46). True proclamation has to base itself on the explicatio of Scripture which can then be applied to our present-day situation (Potgieter 1989:56-57). 


\section{Discussion}

Potgieter does his best to base his conception of authority on the 'objectivity' of the Bible and its message: as divine Word it must be authoritative. In order to uphold this premise he has to 'objectivise' the Word of God and truth, limit human acitivity in the inscripturation and interpretation of the Bible to an absolute minimum, and treat the term 'Word of God' in purely abstract terms.

His argument sometimes runs into contradictions. On the one hand he acknowledges that every biblical author retained 'his own set of memories', used 'his own sources and was limited by his own horizon of knowledge and frame of reference' (Potgieter 1989:30). All these assertions imply full human involvement in the writing of the Bible. But if this is true and if words have meaning, how can the product of their writing remain 'objective'?

But even if one would grant him this notion of objectivity, his argument runs into new difficulties when it comes to the interpretation of Scripture. Consider the following statements (my emphasis):

* 'It is, of course, true that truth has relational aspects, but as such truth is not relational' (Potgieter 1989:35).

- 'Scripture does not become true when it is heard and faithfully known by a person, but is true because it is the Word of God' (Potgieter 1989:35).

- 'Objective clarity as a characteristic of Scripture necessarily follows from the perfection of God's work' (Potgieter 1989:50).

* 'Scripture is not unclear in itself. It is the reader's poor insight that prevents him from understanding what was meant' (Potgieter 1989: 50).

- The basic cause of different interpretations of Scripture is the obscuration of the human mind as a result of the fall. The problem most definitely does not lie with Holy Scripture. As Word of God it is absolutely clear...' (Potgieter 1989: 28).

- 'Even if we always have to say, "In the light of our present knowledge we understand [Scripture] as saying..." truth as such is not relativised' (Potgieter 1989:51).

The Bible is here isolated from its readers and, as it were, viewed in a vacuum. In spite of Potgieter's (1989:32) rejection of a 'philosophical' view of truth these statements reflect a presupposed naive realist or positivist view of truth. But even this epistemologically problematic view of truth does not really safeguard the 'objective' authority of Scripture, since the Bible without readers remains silent. The 'objectively' true and clear Bible thus still has to be interpreted by fallible human beings.

Although Potgieter admits (1989:28), 'When a person...reads or studies the Bible, he necessarily does so with particular presuppositions', he does not reflect on the implications of this statement for his own argument at all, for if it is true that 
reading the Bible necessarily involves human presuppositions, it renders superfluous the battle for the 'objectivity' of the truth contained in the Bible, for what is the sense of 'objective' truth if there exists a rift between the Bible and its modern readers (Potgieter 1989:49), if truth can only be known via human involvement and if human involvement necessarily proceeds from presuppositions?

Potgieter would perhaps argue that a specific set of presuppositions and exegetical rules (Potgieter 1989:29, 32, 33) can guarantee the correct interpretation of Scripture. But how do we arrive at such correct rules? Potgieter $(1989: 32,33)$ argues that such rules, to be correct, should be derived from Scripture itself. But this is begging the question, since if we have to derive exegetical rules from Scripture we have to interpret the Bible. But to interpret Scripture we need correct rules....

Potgieter runs into more difficulties with this line of argument when he rejects such 'Scripturally' attested procedures as pneumatic and allegorical interpretation (Potgieter 1989:32), and states that 'there is no infallible method for the interpretation of Scripture' (Potgieter 1989:51).

Moreover, if correct methods - as prescribed by a specific hermeneutic (Potgieter 1989:28, 29) and a 'sound dogmatic basis' (Potgieter 1989:57) - ensure the correct exposition of Scripture, what becomes of the 'objective clarity' of Scripture? If correct procedures guarantee correct interpretation, it is a small step to a position where official ecclesiastical interpretation or scholarly theology becomes a sine qua non for the correct interpretation Scripture - a position which Potgieter himself (1989:8-10,36), in spite of his assertion that church tradition and dogma play a significant role in correct Scriptural interpretation (Potgieter 1989:45, 57), rejects. As Potgieter (1989:30) himself asks, what would be the sense of Bible reading by lay people if only scholars can tell as what the Bible says?

Potgieter senses the contradictions lurking in the above argument. To escape from the difficulties thus created, he resorts to an appeal for the enlightment of the reader by the Holy Spirit: 'If a preacher really wants to proclaim the Lord's Word with authority, the contents of his preaching may not be anything but what Holy Scripture says...To achieve this he is completely dependent upon the promised guidance by the Holy Spirit' (Potgieter 1989:38 - my emphasis).

Apart from the fact that a complete dependance on the Holy Spirit contradicts the call for sound exegetical methods, it is debatable whether this appeal for enlightment by the Spirit really solves the problem of correct Scriptural interpretation, since Potgieter (1989:38) also asserts that not all preaching of the Word necessarily reflects the Word of God, because one cannot say for sure whether this illumination by the Holy Spirit has indeed taken place in a particular instance (Potgieter 1989: 47). 
If we do not have an infallible method of exegesis and cannot be sure that we have been guided by the Spirit in our interpretation, what is the practical sense of affirming the objective authority of Scripture?

To me the problem with Potgieters's argument lies in the uncritically presupposed naive realistic epistemology with its distinction between 'objective' and 'subjective' knowledge. This naive view implies no less a particular philosophical view of truth than it does the idea of 'relational' truth, which Potgieter (1989:34) rejects because of its philosophical nature.

Although Van Wyk argues more carefully and lays much more stress on the Bible in function the problem with the overall argument remains the same: the moment the 'objective' Word of God (or revelation) is comprehended by humans, it becomes, as it were, 'mixed up' with our presuppositions, and - to use the same terminology - therefore 'subjective'. The checks and balances Potgieter builds into his argument to avoid this inevitability do not help us out of the dilemma, for there is no infallible exegetical method to ensure correct interpretation of the objective Word, and one cannot be sure whether any particular interpreter has in fact been guided by the Spirit.

The argument presented to uphold the 'hard' form of authority he set out to protect thus does not warrant the conclusion. Perhaps the problem lies not only with the presupposed epistemology, but also with the presupposed contents of the concept of authority.

\section{MOSALA (1989)}

Mosala tackles the problem of biblical hermeneutics from a position exactly opposite to that of Van Wyk and Potgieter. Whereas the latter two stress the objective, divine nature of the Bible and its truths, Mosala emphasises its thoroughly human nature.

\subsection{The key concept}

While Potgieter and Van Wyk base their views of Scripture on objective authority and objective revelation respectively, Mosala (1989:8) bases his hermeneutical deliberations on the key concept of 'struggle': 'I argue that the category of struggle provides the lens for reading the text in a liberating fashion as well as the codes for unlocking the possibilities and limitations of the biblical texts.'

Mosala views biblical texts not as containing divinely revealed and infallibly inspired, and therefore authoritative, pronouncements, but as the products of ancient class struggles. 'The form of biblical-hermeneutical appropriation suggested in 
these chapters,' Mosala (1989:11) asserts, 'is deliberately oblivious to the notion of "scriptural authority" which is at the heart of traditional biblical scholarship.'

This choice is based on the materialist insight that ideas, and therefore also texts, "are productions or "signifying practices" that reconstitute in very specific ways the realities of the material conditions of which they are products' (Mosala 1989:7). For instance, Mosala (1989:10) argues, traditional biblical scholarship's quest for the historicity and authorial integrity of biblical texts 'define[s] a hermeneutical method rooted in contemporary Western ruling-class anxiety about authenticity'. Similarly, certain biblical pronouncements reflect the ideas of ancient ruling classes bent upon maintaining the social status quo, while others reflect the struggle of the oppressed and poor for liberation from the hegemony of the ruling classes.

In order to be able to read the Bible in a truly liberating manner, one thus has to be aware of the fact that not all biblical texts are liberating in nature. To get to the authentic biblical message of liberation one has to discern which texts or portions of texts originated from the struggle of the oppressed for liberation.

\subsection{The argument}

People's reading of the Bible - whether they are black or white - Mosala (1989:3) asserts, 'is framed by their history and culture'. He therefore consciously chooses a (materialist) hermeneutical model that can expose the class, ideological and cultural assumptions underlying not only models of biblical interpretation, but also biblical texts themselves.

'Black theology has exploded the myth of rational objectivity in theology, which presumes to preclude cultural and ideological conditioning' (Mosala 1989:13). Yet, many black liberation theologians have uncritically taken their exegetical starting point in the notion 'that the Bible is the revealed Word of God' (Mosala 1989:15), a notion carrying the implication that there is such a thing as a non-ideological appropriation of Scripture, to which there is but one response, namely obedience. At best, every-day human experience can be seen in the light of the Word of God, but not vice versa (Mosala 1989:17).

Viewed in this way the Bible becomes an ahistorical interclassist document, the truth of which is not historical, cultural and economic, but eternal and has to be 'applied to' or 'contextualised in' particular situations (see Potgieter 1989:54-57). But the relevance of the Bible's message does not flow from its idealistically construed universality. On the contrary, its relevance issues from its very character as a historical, cultural, political and economic product (Mosala 1989:19-20). The biblical texts bear the marks of their origins and history, marks which are effectively con- 
cealed by the notion of the Bible as the eternal Word of God and by the harmonisations of cultural and ideological differences in these texts (Mosala 1989:20).

Through its uncritical acceptance of the ideological assumptions of classical Western theology, black theology has fallen prey to the idea of a universal, ahistorical, non-ideological Word of God that has to be 'applied' to concrete life situations (Mosala 1989:22). This has caused black theologians to use the Bible very selectively without having been able to tell why they chose certain and glossed over other sections of the Bible (Mosala 1989:11, 17-18).

However, by consciously taking 'the struggle' as the hermeneutical 'lens' it becomes possible to recognize the oppressor and oppression in the biblical texts themselves (Mosala 1989:26). And it is necessary to do so, since the reason why the ruling classes and oppressors can lay claim to 'biblical support' for their exploitation and oppression is that such conduct can in fact be biblically underscored (Mosala 1989: 27). For instance, the texts on David and Solomon reveal a God of 'law and order' supporting oppressive measures (Mosala 1989:17). Such a theology is incompatible with, for instance, the original exodus theology (Mosala 1989:20). Using 'the struggle' as hermeneutical lens allows one to tell why certain sections of the Bible hamper the liberation process. Instead of sharing the 'universal abstract' (Mosala 1989:26) assumption of classic Western theology that the whole Bible is the Word of God, liberation theology can, by applying the yardstick of 'the struggle', discern the liberation trajectory running through the Bible - albeit 'underneath' the present biblical text or even in the societies 'behind' the text (Mosala 1989:27). So, for instance, the liberating message of Isaiah 61:1-7 has been reworked according to the 'ruling class ideology' (Mosala 1989:38).

This is why it is imperative to speak about biblical messages rather than of the biblical message, about biblical Gods rather than about the biblical God. The Bible bears witness to more than one God: the God of the oppressed as well as to the God of the oppressor. It is for this reason that the Bible cannot be read as a 'bill of rights' of as an 'ontological product' in which 'the human dignity of all people...is ontologically inscribed' (Mosala 1989:29).

It is thus not enough just to be 'existentially committed to the struggle of the oppressed...One must also effect a theoretical break with the assumptions and perspectives of the dominant discourse of a stratified society' (Mosala 1989:39), including certain methods of sociological analysis (Mosala 1989:43ff, 55-65) used to interpret the Bible.

Mosala does not object to the fact that biblical scholars hold particular ideological and political views or that they use sociological methods in the interpretation of the Bible. It is humanly impossible to live without such convictions, and sociological 
interpretations of the Bible can indeed be fruitful. What he pleads for is that biblical scholars should openly acknowledge their class interests, so that the perspective from which they interpret the Bible may become explicit and the social limitations of the methods they use apparent (Mosala 1989:65).*

\subsection{Discussion}

Mosala takes the role of the reader seriously, discards epistemologically problematic dichotomies (such as eternal-historical, subject-object and exposition-application) and rightly emphasises the historical nature of biblical witness and human understanding. That one cannot speak about the Bible in the abstract, but only of the Bible-in-function and of the Bible as it is used - as Van Wyk also asserts - is a welcome insight. He rightly criticizes traditional Western biblical hermeneutics of being by and large unaware of the ideological nature and implications of its presuppositions. His insight that traditional theology, even though it professes the whole Bible to be the Word of God, always operates with a canon within the canon, without supplying convincing arguments for the relevant selectivity, is also useful. He is neither negatively inclined towards 'philosophy' as are Potgieter and Van Wyk, nor afraid to admit the ideological nature of his stance, and consequently accepts the theoretical relativity of biblical interpretation.

Mosala's critical approach takes us a long way towards becoming aware of what we are doing when we read the Bible, thereby urging biblical interpreters to put their presuppositions 'on the table' and make conscious choices. It certainly is not enough to admit that one works from certain presuppositions and then to simply ignore their influence on one's interpretation.

Mosala's book does raise a number of questions, though. He discards the notion 'the Word of God', because that term entails, to his mind, the notions of eternal, ahistorical truth and a particular form of authority. This is, of course, not necessarily true. 'Word of God' can be defined in various ways and has in fact been defined differently over the centuries (Deist 1978).

Mosala seems to be reacting against a particular definition of the term - probably the traditional Methodist or South African notion. But the term 'Word of God' is not without its own history. Had Mosala followed Van Wyk's example by critically discussing the history of that term over the centuries and (unlike Van Wyk) in various theological traditions, he would perhaps have found other interpretations of the term that would relate the Bible to God without severing 'Word of God' from human history.

- The rest of Mosala's book dcals with the exposition of a matcrialist reading strategy and its practical application to the book of Micah and a section from Luke. 
It is not clear whether Mosala takes the remainder of the Bible (that is, what is left after its dissection by the hermeneutical key of 'struggle') as in any way related to God or whether he somehow operates with a concept of divine revelation - however 'weak' and relative the definition of such revelation.

Mosala (1989:28) does speak of a theology of struggle, but fails to say what forms the basis of this theology. He also argues (Mosala 1989:28) that the Bible bears witness to several Gods - thereby implying that not all of them could be accepted as the true God - but fails to explain the relationship between God and the Bible. He also speaks about the function of the Bible in communities of faith (Mosala 1989:192), but he fails to be explicit about the role of faith in biblical interpretation. He thus keeps us in the dark regarding the connections between God, the Bible, theology, faith and Bible readers, and does not explain why the Bible could help us in any way to relate our lives to the will of God.

It is precisely in order to get to grips with these questions of relationship that the traditional church speaks about inspiration and authority, and it is these questions the two other authors discuss - albeit along lines which Mosala rightly criticises. It is one thing to criticize traditional Western theology - and Mosala does this very effectively - but criticism of solutions should not supply a licence to ignore the problem.

Mosala accuses black theologians of an incomplete, merely existential commitment to the struggle, while following in the tracks of traditional Western theology for the rest. I get the uneasy impression that he does the opposite by following in the footsteps of materialism and simply presupposing an unreflected and unexpressed existential commitment to the Bible.

Another problem is this: Mosala criticizes black theologians like Boesak and Tutu of random selectiveness in their choice of biblical texts. This may be true, but what makes the category of struggle the true measure of the canon Mosala reconstructs from the biblical text? With all the compassion one has for oppressed people, I find no rational (epistemological) reason (the kind of argument Mosala uses against traditional theology) why the struggle should be the (only) correct principle of selection.

Mosala would perhaps argue that the struggle as hermeneutical lens follows from one's ideological preference, and one has to applaud his frankness with regard to his materialist sociopolitical position. But his analysis of society - which seems to provide the canonical yardstick for what is to be selected from the Bible as the will of God (?) - is from the viewpoint of methodology not really that different from other possible analyses, for it is founded on just another abstract Western social theory which has not been developed from within the struggle itself. The inventor of 
the philosophy of historical materialism was a middle-class student of law and philosophy, a lecturer and newspaper editor, who devised his theory in the confines of the British Museum. What, then, makes his social theory superior to other theories devised by other middle-class university lecturers confined to their studies? This may be a crucial question.

As a social theory, historical materialism is as abstract and reductionist as idealism. I admit that materialism is a very convenient theory for conscientisation, the fight against exploitation, the explanation of some revolutions and even for discovering certain social powers at work in the societies in which the Bible originated, but convenience is not a rational category. If such a choice is simply a matter of faith, we end up in another form of fideism, of which traditional conservative Western theology may also be accused.

A last point: Like Mosala's 'lens', Afrikaner civil religion, which produced the ideology of apartheid, had also been born in fairly radical opposition to current theological traditions and social theories and had, like Mosala's hermeneutics, been based upon the consciously chosen hermeneutical lens of 'the people'. A few quotations will illustrate my point (see Deist 1990 for details).

Lategan (1944:13) wrote (my translation): 'We also live through difficult, dangerous and worrying times [made worse by] the current of humanism...And humanism is supported by its powerful accomplices of rationalism, naturalism, materialism..., totalitarianism, and communism.' What was needed, according to Afrikaner nationalists, was something radically different from these currents. The editor of the Kerkbode (Redaksioneel 1948:392) explained, 'What we need today, is the brisking up of a true reformed piety among our people that will be in accordance with Scripture, confession and the Calvinist character of our people' (my emphasis). They found that lacking hermeneutical lens in, what I elsewhere (Deist 1991) called, 'Boerecalvinisme'. Of this hermeneutical invention Erasmus (1946) said that it did not want to bear the mark of an imported Calvinism, nor to imitate outlandish Calvinism, or to be the mouth-piece of overseas Calvinism.' It is a form of Calvinism following the 'Boerepad', and had been 'adapted to our national differences of predisposition, the nature of our people, our history and circumstances' (my emphasis) - very much the same call as Mosala seems to extend to fellow black theologians. Groenewald (1952:509) describes this kind of 'Boer' theology as 'a theology sprouting forth from our own soil and the history of the people' (my emphasis), a theology that can 'prepare better spiritual food for the people of this soil than can any foreign theology'.

This hermeneutical lens had also been fairly intolerant of other possible perspectives. In documents from those circles one often comes across the phrase contra principia negantem, non est disputandum (e g Kock 1936:85). The Free State corres- 
pondent of the Kerkbode even stated ('Uit die Vrystaat' 1948:62): 'For the church of Christ there must exist a doctrine next to the Bible...If a person now comes and does not bring this doctrine, church members must leave aside their unscriptural love and tolerance.'

We all know today, half a century later, the consequences of this hermeneutical novelty.

I am not accusing Mosala of re-erecting a sort of black counterpart for 'Boerecalvinisme'. I am simply pointing out certain parallels to earlier South African attempts at creating an 'own', somewhat partisan, lens for scriptural interpretation, and plead for a hard look at the possible consequences of the new, 'own' lens Mosala proposes.

One could thus say that Mosala's criticism of the unreflective nature of traditional Western theology is necessary, to the point and effective, but that he does not put all the cards on the table regarding his view of Scripture and theology or regarding the rational arguments for the choice of his hermeneutical lens. Some important things are thus missing from his hermeneutics as well, not the least of which is a prognosis of the consequences of such scriptural interpretation.

\section{CONCLUSION}

The only common ground between the three authors, it seems, is the fact that each, for his own reasons, reflects on the Bible and its interpretation. And that is too small a basis for any meaningful discussion. It is thus as yet too early to prepare a round table for them.

If we had to identify a few items on which talks about talks could perhaps take place, we could mention the following.

First of all, the two Reformed authors would have to take a fresh look at the naive realist and/or positivist epistemology underlying the presuppositions they take for granted. It is this epistemology that causes the problem of 'subjectivity' versus 'objectivity' - a problem which both these authors failed to solve. Perhaps they can learn from Mosala not to fear or to be suspicious of 'philosophy', but to put all their philosophical cards on the table.

Secondly, these two scholars will have to take Mosala's point of the ideological nature of presuppositions and hermeneutics seriously. For instance, I suspect that the notion of authority underlying their presentations flows from the authoritarian (perhaps even colonial) culture in which they grew up, and perhaps also from a measure of anxiety stemming from a (subconscious) feeling of 'loss of control' over the theological (and political?) scene. One has to be very honest here, because such unnamed feelings of superiority or fear can seriously misdirect talks. They should per- 
haps consider Mosala's (1989:192) remark: 'South Africa is probably the best, though not the only, modern example of a country in which the ruling political group has consciously developed a biblical hermeneutics that reproduces and sustains its ideological and political interests.'

Thirdly, the Reformed scholars will have to reconsider the implications of the profession that God revealed himself in human history and through ordinary human beings. They may then find it much more difficult to formulate a theory on inspiration that will, at the same time, safeguard their notion of revelation and authority and leave room for God's radical historical incarnation." Mosala seems to take this historical incarnation seriously, since he even accepts that ordinary human power struggles are reflected in Biblical texts, while the two Reformed scholars - Potgieter more so than Van Wyk - seem to be uneasy with the reality of the human form of God's Word in Scripture and seem to prefer a less human Bible.

Fourthly, the two Reformed scholars will have to admit that there is hardly any doctrinal or ethical stance which will be supported by the whole Bible. That is, they will have to admit that the Bible often provides us with more than one answer to our questions and that it is difficult - if not sometimes impossible - to find a yardstick by which to measure these views. This insight will urge them to search more seriously for a way of evaluating biblical pronouncements.

Fifthly, Mosala will have to rethink the question of why we read the Bible, after all. He rightly stresses the human nature of the texts we read, but he does not tell why the Bible is important or relevant. The incorrect definition of terms (such as 'revelation' or 'Word of God') does not imply the falsity of the notion expressed by them. He should perhaps spell out in more detail his views on revelation and faith and their relation to biblical hermeneutics.

Sixthly, Mosala should, while inculcating the consequences of earlier attempts at using a partisan lens in biblical hermeneutics, advance rational arguments for choosing his hermeneutical key. Materialism may be a very useful tool to certain ends but, as the saying goes, 'If the only tool you have is a hammer, you tend to treat everything as if it were a nail'. Materialism will keep on providing the same anwers to questions, thereby ignoring the variety contained in the Bible. An ideologically reduced Bible will certainly make any talks impossible. Should we not perhaps take the contradictory nature of the Bible regarding social issues more seriously, and devise a hermeneutic that can handle these contradictions, rather than to reduce or rewrite the Bible?

- Van Wyk (1989:46) is somewhat sceptical about the analogy between incarnation and inscripturation, but this analogy - if treated as an analogy - can throw some light on the issuc of the human nature of Scripture. See, for instance, Deist (1986), where a whole chapter is devoled to the subject. 
In the seventh place Mosala should perhaps, on the grounds advanced under section 3.3, reconsider his non-negotiable stance regarding materialism as the only really valid hermeneutical strategy, and acknowledge its theoretical, and therefore relative, nature. A non-negotiable stance inevitably renders any talks senseless even among liberation theologians. Perhaps he should clarify his remark (Mosala 1989:192) that in a society as divided as ours there 'must certainly be a plurality of biblical hermeneutics', for it is not clear whether he states a fact or paints an ideal state of affairs. If black theology can only be done on the basis of an ideologically, epistemologically, and theoretically different biblical hermeneutics' as Mosala (1989:192) concludes, we are faced with completely different paradigms. If this is so, I see little prospect for white and black theologies to strive towards any sort of common goal, or for any meaningful discussion to take place.

\section{Works cited}

Deist, F E 1978. 'The Bible - the Word of God. Or: searching for the pearl in the oyster' in Vorster, W S (ed) 1978, Scripture and the use of Scripture, 41-74. Pretoria: UNISA.

--- 1986. Kan ons die Bybel dan nog glo? Pretoria: Van Schaik.

--- 1990. Notes on the context and hermeneutics of Afrikaner civil religion in Kritzinger, J N J \& Saayman, W A (ed) 1990, Mission in creative tension: A dialogue with David Bosch, 124-139. Pretoria: SA Missiological Society.

--- 1991. Objektiewe Skrifuitleg? Kanttekeninge by Skrifuitleg in die Ned Geref Kerk 1930-1990. HTS 47, 367-385.

Die Kerksaak tussen prof J du Plessis en die Ned Geref Kerk in Suid-Afrika 1932. Cape Town: Nasionale Pers.

Erasmus, D F 1946. Ons eie Calvinisme. Die Gereformeerde Vaandel 14/11, 11-12.

Groenewald, E P 1952. Die stand van die teologiese wetenskap in Suid-Afrika. Die Kerkböde 12 Maart, 506-509, 513.

Kock, P de B 1936. Calvinisme en etiek. Die Gereformeerde Vaandel 4/3, 84-88.

Lategan, D 1944. Die Gees van Elia. Die Gereformeerde Vaandel 12/3, 10-14.

Mosala, I J 1989. Biblical hermeneutics and black theology in South Africa. Grand Rapids: Eerdmans.

Potgieter, P C 1989. Skrif, dogma en verkondiging. Cape Town: Lux Verbi.

Redaksioneel 1948. Ons verhouding tot die sektes. Die Kerkbode 25 Februarie, $392-$ 393.

'Uit die Vrystaat' 1948. Christelike onverdraagsaamheid. Die Kerkbode 14 Januarie, 60-62. 
Van Wyk, J H 1990. Die Woord is waardevol: 'n Dogmatiese besinning oor die reformatoriese Skrifheskouing. Potchefstroom: PU vir CHO.

Van Huyssteen, J W V 1986. Teologie as kritiese geloofsverantwoording. Pretoria: HSRC. 